\section{Blackberry Propagation Limitations When Using Floricane Cuttings}

\author{
Abigail R. Debner ${ }^{1}$, Harlene Hatterman-Valenti ${ }^{1,3}$, and \\ Fumiomi Takeda ${ }^{2}$
}

AdDitional INDEX wORDs. adventitious roots, auxin, hardwood, IBA, rooting, Rubus

Summary. Outdoor production of floricane-fruiting (FF) blackberry ( Rubus subgenus $R u b u s$ ) is problematic in the Northern Great Plains region of the United States because cane injury and plant death will occur from exposure to temperatures $-15^{\circ} \mathrm{C}$ and colder. An annual FF blackberry production system using hardwood floricane cuttings would overcome some of the existing limitations of traditional production methods. Several experiments were performed to induce adventitious root formation from one-node hardwood floricane blackberry cuttings taken in winter for the purpose of subsequent growth of a floral shoot. One-node hardwood cuttings of multiple blackberry cultivars (Apache, Arapaho, Kiowa, Osage, Ouachita, Siskiyou, and Triple Crown) were evaluated for rooting potential with and without auxin treatments. Root formation was virtually nonexistent for 'Apache', 'Kiowa', and 'Triple Crown' regardless of the auxin treatment. In general, lower auxin concentrations and the powder formulation produced more roots and had higher root ratings. However, rooting success of cuttings and plant development was low regardless of the rooting method used. Adventitious root production of one-node dormant hardwood FF blackberry cuttings for use in an annual production system had low success regardless of the cultivar, auxin application, rate, and formulation. The variable propagation success rates using single-node hardwood cuttings from 'Apache', 'Arapaho', 'Kiowa', 'Osage', 'Ouachita', 'Siskiyou', and 'Triple Crown' plants grown in containers in North Dakota suggested insufficient rooting success for the recommendation of this practice. Additionally, the results suggested these cultivars are not suitable using this method for an annual production system or as a means for large-scale propagation. Although this approach to developing plants from cuttings is of great interest, without a more effective FF blackberry cutting rooting method that can progress through fruit production, an annual blackberry production system in the Northern Great Plains region of the United States is unlikely.

$\mathrm{F}$ loricane-fruiting blackberry do not produce fruit in the Northern Great Plains region of the United States unless the primocanes are protected by some method such as laying canes parallel to the ground using a rotating cross-arm system and rowcovers to protect from low winter temperatures (Mettler and Hatterman-Valenti, 2018). Even

Received for publication 2 Jan. 2019. Accepted for publication 26 Feb. 2019.

Published online 11 April 2019.

${ }^{1}$ Plant Sciences Department, North Dakota State University, P.O. Box 6050, Dept. 7670, Fargo, ND 58108

${ }^{2}$ United States Department of Agriculture, Agricultural Research Service, Appalachian Fruit Research Station, 2217 Wiltshire Road, Kearneysville, WV 25430

${ }^{3}$ Corresponding author. E-mail: h.hatterman.valenti@ ndsu.edu.

This is an open access article distributed under the CC BY-NC-ND license (https://creativecommons.org/ licenses/by-nc-nd/4.0/).

https://doi.org/10.21273/HORTTECH04266-18 under these protected conditions, fruit production was generally low, regardless of the cultivar. However, FF blackberry could be grown in an annual production system using dormant hardwood cuttings when they have achieved their chilling requirement for breaking physiological dormancy. If hardwood cuttings could be successfully rooted, then greenhouse growers could produce miniature $(\approx 30 \mathrm{~cm}$ long stems $)$ blackberry plants that develop a flower shoot and fruit within several months. Cuttings would be taken during the dormant season to root, flower, and fruit for an annual high-density $(\approx 75,000$ potted plants/acre) production system that should produce $\approx 5000 \mathrm{lb} /$ acre local fruit during an off-peak time (F. Takeda, unpublished data).

Blackberry is typically propagated from leaf-bud cuttings during the summer and by tip-layering primocanes during late summer (Hartmann et al., 2011; Takeda and Soria, 2011). Other successful methods of commercial blackberry propagation include root cuttings and tissue culture (Caldwell, 1984; Hartmann et al., 2011). Attempts to root hardwood cuttings of FF blackberry have produced variable success rates (Bray et al., 2003; Gonçalves et al., 2012; Lopez-Medina and Moore, 1997; Takeda et al., 2011; Zimmerman et al., 1980). There has been no consensus regarding the best method of rooting hardwood cuttings. Root initiation on blackberry cuttings appears to be cultivar-dependent regardless of the methods used (e.g., cutting material, time of collection, and auxin application). Bray et al. (2003) used three thornless cultivars (Apache, Arapaho, and Navaho) and found that the rooting response to auxin application to the cut end of hardwood cuttings was variable among cultivars. For 'Apache', the application of $0.3 \%$ indole-3-butyric acid (IBA) in water as a 1 - to 3 -s quick dip caused an increase in root formation; however, for 'Arapaho' and 'Navaho', the treatment decreased root formation compared with that of untreated cuttings. The study also found cuttings rooted well using a method similar to that of other studies involving hardwood cuttings and placing them in a peat perlite medium mix with intermittent

\begin{tabular}{llll}
\hline $\begin{array}{l}\text { Units } \\
\begin{array}{l}\text { To convert U.S. to SI, } \\
\text { multiply by }\end{array}\end{array}$ & U.S. unit & SI unit & $\begin{array}{l}\text { To convert SI to U.S., } \\
\text { multiply by }\end{array}$ \\
\hline 0.4047 & $\mathrm{acre}(\mathrm{s})$ & $\mathrm{ha}$ & $2.471 \mathrm{l}$ \\
0.3048 & $\mathrm{ft}$ & $\mathrm{m}$ & 3.2808 \\
0.0929 & $\mathrm{ft}^{2}$ & $\mathrm{~m}$ & 10.7639 \\
2.54 & inch $(\mathrm{es})$ & $\mathrm{cm}$ & 0.3937 \\
25.4 & inch $(\mathrm{es})$ & $\mathrm{mm}$ & 0.0394 \\
1.1983 & lb/100 gal & $\mathrm{g} \cdot \mathrm{L}^{-1}$ & 0.8345 \\
1.1209 & $\mathrm{lb} / \mathrm{acre}$ & $\mathrm{kg} \cdot \mathrm{ha}^{-1}$ & 0.8922 \\
1 & $\mathrm{ppm}$ & $\mathrm{mg} \cdot \mathrm{L}^{-1}$ & 1 \\
0.9464 & $\mathrm{qt}$ & $\mathrm{L}$ & 1.0567 \\
$\left({ }^{\circ} \mathrm{F}-32\right) \div 1.8$ & ${ }^{\circ} \mathrm{F}$ & ${ }^{\circ} \mathrm{C}$ & $\left({ }^{\circ} \mathrm{C} \times 1.8\right)+32$
\end{tabular}


misting. In contrast, Takeda et al. (2011) developed a protocol for rooting one-node hardwood cuttings without using intermittent mist in a greenhouse setting. Hardwood cuttings were taken from 'Siskiyou' and 'Triple Crown' laterals after the canes had undergone an outdoor dormancy period and axillary buds had undergone floral bud initiation and differentiated floral bud primordia. One-node leafless cuttings were wrapped with moistened paper towels and placed in a sealed plastic bag under low light at room temperature with weekly hand misting. Both cultivars produced adventitious roots within 10 to $14 \mathrm{~d}$, with most of the roots forming at the base of the bud. Soon after root formation, a flower shoot emerged from the axillary bud; $\approx 2$ months later, the flowers on the resulting miniature plants (e.g., 30- to 50-cm-tall plants with a single flower shoot) bloomed. Similarly, Gonçalves et al. (2012) used two-node floricane cuttings from 'Arapaho', 'Ouachita', and 'Karaka Black' to examine the cane position (top, middle, and bottom) influence on rooting and subsequent flower and fruit production. These findings indicated that cuttings of FF blackberries taken during early winter or even after flower bud differentiation had occurred could successfully produce a plant that initiates flowers and then fruit.

The method of rooting hardwood blackberry cuttings developed by Takeda et al. (2011) would be ideal for annual production of $\mathrm{FF}$ blackberry in the Northern Great Plains region, where winter temperatures cause severe cane injury and dieback. By using one-node cuttings from plants grown in nursery pots and stored in a cooler, one could obtain miniature plants for an annual production system that is feasible in northern climates. The poor rooting success of hardwood cuttings could be overcome by the application of auxin, because it has been reported to benefit rooting in some cases (Bray et al., 2003; Lopez-Medina and Moore, 1997).

Although previous studies have researched the use of leafless onenode or two-node floricane cuttings for the purpose of subsequent flowering and fruiting, the use of auxin has not been fully explored in these instances (Gonçalves et al., 2012;
Takeda et al., 2011). There are currently no widely accepted recommendations for the use of auxin for hardwood cuttings of blackberry, and minimal research exists regarding the appropriate form and concentration. Studies involving auxin used on hardwood cuttings reported that it was applied with an intermittent mist in a greenhouse setting in the form of a powder or liquid comprising 0.3\% IBA (Bray et al., 2003; LopezMedina and Moore, 1997). The roles of different rates of IBA or applications of a different auxin hormone group, such as 1-naphthaleneacetic acid (NAA), have not been investigated for hardwood blackberry cuttings.

The objective of this study was to evaluate several methods of rooting hardwood cuttings of FF blackberries to be used in an annual production system. Specifically, we examined the effects of auxin, rooting environment, cultivar, and age/growing location of the mother plant (established plants in-ground vs. young plants in a cooler).

\section{Materials and methods}

General procedures. Several experiments were performed in succession with dormant hardwood blackberry cuttings (one cutting/ experimental unit) to examine the effects of auxin, rooting environment, cultivar, and plant age/growing location on adventitious root production. The objective of the first experiment was to determine the effects of the liquid auxin quick dip on adventitious root production for multiple blackberry cultivars in two different rooting environments. The objective of the second experiment was to determine whether the age of the plant, cultivar, rooting method, and auxin concentration or formulation impacted the production of adventitious roots. The objective of the third experiment was to determine if different auxin concentrations, types, or formulations impacted adventitious root formation when 'Siskiyou' was of two different plant ages. The quick dip auxin treatments followed traditional standards and consisted of 1000-ppm (0.1\%), 3000-ppm (0.3\%), $5000-\mathrm{ppm}(0.5 \%)$, and $8000-\mathrm{ppm}$ $(0.8 \%)$ liquid solutions of either aqueous potassium salt IBA [K-IBA (Sigma-Aldrich, Burlington, MA)] mixed with distilled water or NAA (Sigma-Aldrich) mixed with 50\% ethanol and $50 \%$ distilled water as 10 -s dips of the basal end of the cuttings. Auxin was also applied in powder form as $0.1 \%$ IBA (Hormex No. 1; Maia Products, Westlake Village, CA), $0.3 \%$ IBA (Hormex No. 3; Maia Products), and $0.8 \%$ IBA (Rhizopon AA \#3; Hortus USA Corp., New York, NY), with cuttings dipped in tap water before being dipped in the powder. An untreated control group was also established in which cuttings were only dipped in tap water. All cuttings were $\approx 1.5$ inches long and were treated with a captan fungicide dip for $2 \mathrm{~min}$ at a concentration of $0.98 \mathrm{lb}$ a.i. per 100 gallons of water (Captan 50 Wettable Powder; Arysta LifeScience, Cary, NC) before auxin application. To evaluate the rooting method, half of the cuttings for Expt. 1 and Expt. 2 were placed in a medium mixture of one part peat (Sunshine Canadian Sphagnum Peat Moss; Sun Gro Horticulture, Agawam, MA) to one part perlite (Horticultural Grade Perlite Coarse; Perlite Vermiculite Packing Industries, North Bloomfield, $\mathrm{OH}$ ) by volume. Cuttings for Expt. I were placed in 2.5-inch square plastic pots (2.5 Kord Traditional Square Pot; The H.C. Co., Middlefield, OH), whereas cuttings for Expt. 2 were placed in 1206 cell packs (T.O. Plastics, Clearwater, MN). Care was taken to ensure that the bud on the cuttings was not buried beneath the surface of the medium. The other half of the cuttings for Expt. 1 and Expt. 2 and all the cuttings for Expt. 3 were placed between moistened paper towels, as reported by Takeda et al. (2011). All cuttings located in both the medium and the paper towels were then placed in plastic bags that were kept open 1 inch for air ventilation and subjected to low light conditions $\left(15 \mu \mathrm{mol} \cdot \mathrm{m}^{-2} \cdot \mathrm{s}^{-1}\right.$ ) on a light bank grow cart in a laboratory room with an 8-/16-h day/ night cycle. The cuttings were held at room temperature $\left(72{ }^{\circ} \mathrm{F}\right)$ and misted weekly with tap water to maintain moisture levels.

Cuttings were analyzed for adventitious root formation at the base of the bud and stem after 2 weeks. Cuttings in the medium were carefully removed from their pots, and excess media that did not fall away was 
removed with water from a squirt bottle. For each cutting, the number of adventitious roots $\geq 2 \mathrm{~mm}$ and the length of the roots were recorded. Cuttings were also given a root development rating of $0-5: 0=$ dead; $1=$ no callus or roots; $2=$ callus formation; 3 = few short roots; 4 = moderate well-developed roots; and $5=$ many extensive roots. The number of rooted cuttings (cuttings that contained at least one root $\geq 2 \mathrm{~mm}$ ) was also determined. Data were analyzed using PROC MIXED (SAS version 9.3; SAS Institute, Cary, NC). A square root transformation was used for data (root length, root number, and root rating +1 ) when more than one-third of the values were zero. Percentage data were transformed using the arcsine square root transformation method. Data were analyzed as a combined analysis when repeated experiment error mean squares differed by less than a factor of 10 and were considered homogenous. Means were separated, when appropriate, using a pairwise $t$ test $(P \leq 0.05)$. Means were presented as untransformed data. Tests of simple effects were performed using the SLICE function in SAS (SAS Institute) for significant interactions to evaluate the cultivars and auxin concentrations for each rooting method.

ExpT. 1. The objective was to determine which cultivar in combination with the auxin concentration and rooting method produced the best rooting for one-node hardwood cuttings taken from 1-year-old plants grown in 3-qt nursery containers in the field from 1 Apr. to 31 Oct. and then moved to a $38^{\circ} \mathrm{F}$ cooler on the North Dakota State University campus in Fargo [NDSU (lat. 46 $87^{\prime} 59^{\prime \prime} \mathrm{N}$, long. $\left.\left.96^{\circ} 78^{\prime} 17^{\prime \prime} \mathrm{E}\right)\right]$. The six blackberry cultivars used included the erect, thornless cultivars Apache (Clark and Moore, 1999), Arapaho (Moore and Clark, 1993), Osage (Clark, 2013), and Ouachita (Clark and Moore, 2005), the semi-erect, thorny cultivar Kiowa (Moore and Clark, 1996), and the semi-erect, thornless cultivar Triple Crown (Galletta et al., 1998). In Nov. 2014, plants were placed in a walk-in cooler set at $38{ }^{\circ} \mathrm{F}$ to satisfy the chilling requirement; more than $2500 \mathrm{~h}$ of chilling (temperatures $<45^{\circ} \mathrm{F}$ ) (Crandall, 1995) had been achieved when the experiment was started, which was sufficient for all cultivars used. The rooting hormone auxin (K-IBA) was applied to cuttings at rates of 1000 , 3000,5000 , and $8000 \mathrm{ppm}$ as a liquid quick dip in Feb. 2015. The experimental design for this study was a randomized complete block design with seven replications arranged as a $6 \times 5 \times$ 2 factorial ( 6 cultivars, 5 auxin treatments, and 2 rooting methods), which was repeated.

EXPT. 2. Following poor rooting with many of the cultivars examined during Expt. 1, a second experiment was initiated to determine whether age of the plant, cultivar, rooting method, and auxin concentration or formulation influenced adventitious root formation of one-node hardwood blackberry cuttings. The two FF blackberry cultivars evaluated included the thorny, trailing Siskiyou (Finn et al., 1999) and the thornless, semi-erect Triple Crown. Cuttings were taken from plants established in 2002 that were growing at the U.S. Department of Agriculture, Agricultural Research Service, Appalachian Fruit Research Station in Kearneysville, WV [USDA-ARS (lat. 39 $37^{\prime} 06^{\prime \prime} \mathrm{N}$, long. $77^{\circ} 90^{\prime} 79^{\prime \prime} \mathrm{E}$ )], in Jan. 2015 and 2016. The cuttings were $\approx 1.5$ inches long, with the bud located in the center of the cutting. They were treated with the same captan fungicide dip as previously described, wrapped in moistened paper towels placed in sealed plastic bags, and shipped overnight in an insulated foam shipping box to NDSU. Cuttings were also taken from 2 - and 3 year-old plants grown in 3-qt nursery containers in the field from 1 Apr. to 31 Oct.; then, they were moved to a $38^{\circ} \mathrm{F}$ cooler at NDSU to satisfy the chilling requirement; more than $1400 \mathrm{~h}$ of chilling had been achieved at the start of the experiment. Cuttings from both locations were taken at a time when it was ensured that the number of chilling hours required for all cultivars had been performed. The stem lengths of the cuttings were similar and received the same fungicide treatment as those from USDAARS. The rooting hormone auxin was applied at $1000 \mathrm{ppm}$ and $3000 \mathrm{ppm}$ as a K-IBA liquid quick dip and as $0.1 \%$ and $0.3 \%$ IBA powder. The experimental design was a randomized complete block design arranged as a split plot, with the whole plot consisting of the two rooting methods and the subplot consisting of a $2 \times 2 \times 5$ factorial of cultivars, plant age, and auxin concentrations with four replications; this was repeated the following year.

ExPT. 3. Following poor rooting with many of the cultivars examined by Expt. 1, another experiment was initiated to determine if different auxin concentrations, types, or formulations had an impact on adventitious root formation of one-node hardwood cuttings of 'Siskiyou' with two different plant ages. In Jan. 2016, cuttings were taken from USDA-ARS and NDSU plants described for Expt. 2.

The rooting hormone auxin was applied as an IBA powder at $0.1 \%$, $0.3 \%$, and $0.8 \%$, and also as both $\mathrm{K}$ IBA and NAA quick dips at rates of $1000 \mathrm{ppm}, 3000 \mathrm{ppm}, 5000 \mathrm{ppm}$, and $8000 \mathrm{ppm}$. The experimental design was a randomized complete block design with a $2 \times 12$ factorial ( 2 plant ages and 12 auxin concentrations) with 4 replications, which was repeated.

\section{Results}

EXPт. 1. Repeated experiments were found to be homogenous; therefore, they were combined for analysis. The interaction of the cultivar and auxin treatment was significant for root rating. The majority of roots measured were formed at the base of the bud (Fig. 1). The overall observed trend was that increasing auxin concentrations led to decreased root ratings; the root rating with $8000 \mathrm{ppm}$ IBA was lower than the root rating with $1000 \mathrm{ppm}$ IBA for all cultivars (Table 1). Root ratings from untreated cuttings were similar to those treated with $1000 \mathrm{ppm}$ IBA for all cultivars except Osage, suggesting that auxin treatments did not increase rooting at 2 weeks for most cultivars.

A three-way interaction among the rooting method, cultivar, and auxin treatment was significant for the percent of cuttings rooted, root number, and root length; therefore, the cultivar-auxin interaction was evaluated for each rooting method. No differences in the percent of cuttings rooted, root number, and root length were found with the paper towel method for auxin concentrations or cultivars (data not shown) that had extremely low rooting success. Untreated 'Osage' cuttings in 
the peat perlite mixture had higher rooting percentages compared with when they were treated with auxin (Table 2). Only 'Arapaho' cuttings quick-dipped in either $1000 \mathrm{ppm}$ or 3000 ppm IBA produced roots, whereas 'Ouachita' cuttings quickdipped in 1000 ppm IBA produced more roots than that of any other auxin treatment or untreated cuttings. 'Triple Crown', 'Apache', and 'Kiowa' cuttings had very limited rooting success regardless of whether auxin was applied (data not shown).
Root number results mimicked the root length results; therefore, only root length results are discussed. With the peat perlite mixture, 'Arapaho' and 'Ouachita' cuttings produced longer roots with $1000 \mathrm{ppm}$ IBA, whereas 'Osage' cuttings only produced roots with no auxin application (Table 2). The auxin concentration did not influence the root length for 'Triple Crown', 'Apache', or 'Kiowa' cuttings because very few roots were produced (data not shown).
Expt. 2. Repeated experiments were found to be homogenous; therefore, they were combined for analysis. No differences were found between cultivars or plant ages for any of the variables measured (data not shown). The interaction between auxin treatments and the rooting method was significant across cultivars for the number of roots produced and the root rating (Table 3 ).

Cuttings in the peat perlite mixture treated with either $0.1 \%$ or $0.3 \%$ IBA powder produced more roots than
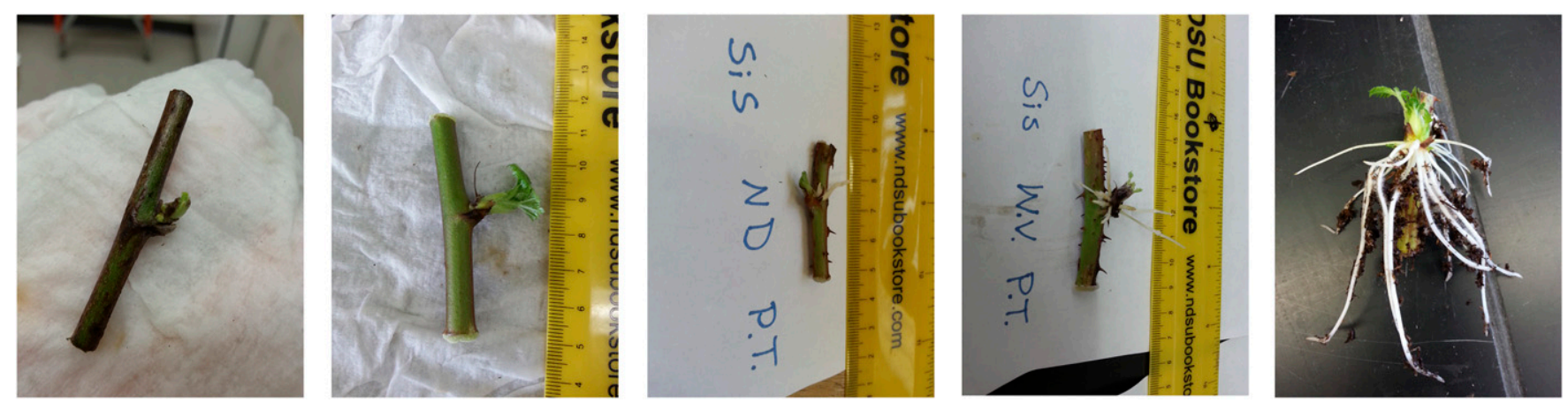

Fig. 1. Photographs of the rooting scale for the one-node hardwood blackberry cuttings after 2 weeks in a rooting environment (left to right): 1 = no callus or roots; 2 = callus formation; 3 = few, short roots; $4=$ moderate well-developed roots; and $5=$ many extensive roots.

Table 1. Effects of the cultivar and auxin treatment [indole-3-butyric acid (IBA)] on the root rating for adventitious root production of one-node hardwood blackberry cuttings for six cultivars in both a peat perlite medium mixture and a damp paper towel after 2 weeks in a rooting environment. ${ }^{\mathrm{g}}$

\begin{tabular}{lcccccc}
\hline & \multicolumn{5}{c}{ Root rating $(\mathbf{0}-\mathbf{5} \text { scale })^{\mathbf{x}}$} \\
\cline { 2 - 6 } Auxin $^{\mathbf{y}}$ & Apache & Arapaho & Kiowa & Osage & Ouachita & Triple Crown \\
\hline Untreated & $1.7 \mathrm{a}^{\mathrm{w}}$ & $2.0 \mathrm{ab}$ & $1.4 \mathrm{a}$ & $1.7 \mathrm{a}$ & $2.0 \mathrm{ab}$ & $2.0 \mathrm{a}$ \\
1000 ppm IBA quick dip & $1.4 \mathrm{ab}$ & $2.2 \mathrm{a}$ & $1.2 \mathrm{ab}$ & $1.1 \mathrm{~b}$ & $2.2 \mathrm{a}$ & $1.7 \mathrm{ab}$ \\
3000 ppm IBA quick dip & $1.1 \mathrm{bc}$ & $2.0 \mathrm{ab}$ & $0.6 \mathrm{c}$ & $1.1 \mathrm{~b}$ & $1.9 \mathrm{abc}$ & $1.6 \mathrm{bc}$ \\
5000 ppm IBA quick dip & $1.1 \mathrm{bc}$ & $1.9 \mathrm{abc}$ & $1.2 \mathrm{ab}$ & $0.6 \mathrm{c}$ & $1.7 \mathrm{abc}$ & $1.0 \mathrm{~d}$ \\
8000 ppm IBA quick dip & $0.7 \mathrm{~cd}$ & $1.5 \mathrm{c}$ & $0.7 \mathrm{c}$ & $0.4 \mathrm{c}$ & $1.4 \mathrm{~d}$ & $0.5 \mathrm{e}$ \\
\hline
\end{tabular}

${ }^{\mathrm{z}}$ Cuttings were held in the auxin liquid quick dip for $10 \mathrm{~s}$. Untreated cuttings were dipped in water. Cuttings were either placed in a peat perlite medium mixture or wrapped in damp paper towels. All cuttings were placed in a plastic bag to maintain a humid environment. The majority of roots measured were formed at the base of the bud.

${ }^{\mathrm{y}} 1 \mathrm{ppm}=1 \mathrm{mg} \cdot \mathrm{L}^{-1}$

${ }^{\mathrm{x}} 0=$ dead; 1 = no callus or roots; 2 = callus formation; 3 = few short roots; 4 = moderate well-developed roots; 5 = many extensive roots.

${ }^{\text {w } M e a n s ~ f o l l o w e d ~ b y ~ t h e ~ s a m e ~ l e t t e r ~ w i t h i n ~ e a c h ~ c u l t i v a r ~ a r e ~ n o t ~ s i g n i f i c a n t l y ~ d i f f e r e n t ~ a c c o r d i n g ~ t o ~ a ~ p a i r w i s e ~} t$ test $(P>0.05)$.

Table 2. Effects of cultivar and auxin treatment [indole-3-butyric acid (IBA)] on the percent of cuttings rooted and live root lengths for adventitious root production of one-node hardwood blackberry cuttings for three cultivars in a peat perlite medium mixture after 2 weeks in a rooting environment. ${ }^{\mathrm{z}}$

\begin{tabular}{|c|c|c|c|c|c|c|}
\hline \multirow[b]{2}{*}{ Auxin $^{y}$} & \multicolumn{3}{|c|}{ Rooted (\%) } & \multicolumn{3}{|c|}{ Live root length $(\mathrm{cm})^{y}$} \\
\hline & Arapaho & Osage & Ouachita & Arapaho & Osage & Ouachita \\
\hline Untreated & $0 c^{x}$ & $23 \mathrm{a}$ & $0 \mathrm{c}$ & $0.00 \mathrm{c}$ & $0.29 \mathrm{a}$ & $0.00 \mathrm{~b}$ \\
\hline 3000 ppm IBA quick dip & $27 \mathrm{ab}$ & $0 \mathrm{~b}$ & $6 \mathrm{bc}$ & $0.15 \mathrm{~b}$ & $0.00 \mathrm{~b}$ & $0.03 \mathrm{~b}$ \\
\hline 5000 ppm IBA quick dip & $0 \mathrm{c}$ & $0 \mathrm{~b}$ & $15 \mathrm{~b}$ & $0.00 \mathrm{c}$ & $0.00 \mathrm{~b}$ & $0.03 \mathrm{~b}$ \\
\hline 8000 ppm IBA quick dip & $0 \mathrm{c}$ & $0 \mathrm{~b}$ & $0 \mathrm{c}$ & $0.00 \mathrm{c}$ & $0.00 \mathrm{~b}$ & $0.00 \mathrm{~b}$ \\
\hline
\end{tabular}

${ }^{\mathrm{z}}$ Cuttings were held in the auxin liquid quick dip for $10 \mathrm{~s}$. Untreated cuttings were dipped in water. Cuttings were either placed in a peat perlite medium mixture or were wrapped in damp paper towels. All cuttings were placed in a plastic bag to maintain a humid environment. The majority of roots measured were formed at the base of the bud. ${ }^{\mathrm{y}} 1 \mathrm{ppm}=1 \mathrm{mg} \cdot \mathrm{L}^{-1}, 1 \mathrm{~cm}=0.3937$ inch.

${ }^{\mathrm{x}}$ Means followed by the same letter within the same cultivar are not significantly different according to a pairwise $t$ test $(P>0.05)$. 
Table 3. Effects of auxin treatment [indole-3-butyric acid (IBA)] and rooting method on root length, root number, root rating, and percent of cuttings rooted for adventitious root production of one-node hardwood 'Triple Crown' and 'Siskiyou' blackberry cuttings rooted after 2 weeks in a rooting environment. ${ }^{\mathrm{z}}$

\begin{tabular}{|c|c|c|c|c|c|c|c|c|}
\hline \multirow[b]{2}{*}{ Auxin $^{y}$} & \multicolumn{2}{|c|}{ Rooted (\%) } & \multicolumn{2}{|c|}{ Roots (no.) ${ }^{x}$} & \multicolumn{2}{|c|}{ Root length $(\mathrm{cm})^{\mathrm{y}}$} & \multicolumn{2}{|c|}{ Root rating ( $0-5$ scale $)^{v}$} \\
\hline & $\begin{array}{c}\text { Peat } \\
\text { perlite }\end{array}$ & $\begin{array}{l}\text { Paper } \\
\text { towel }\end{array}$ & $\begin{array}{c}\text { Peat } \\
\text { perlite }\end{array}$ & $\begin{array}{l}\text { Paper } \\
\text { towel }\end{array}$ & $\begin{array}{c}\text { Peat } \\
\text { perlite }\end{array}$ & $\begin{array}{l}\text { Paper } \\
\text { towel }\end{array}$ & $\begin{array}{c}\text { Peat } \\
\text { perlite }\end{array}$ & $\begin{array}{l}\text { Paper } \\
\text { towel }\end{array}$ \\
\hline Untreated & 22 & 21 & $0.9 \mathrm{~d}^{\mathrm{u}}$ & $1.8 \mathrm{a}$ & 0.25 & 0.10 & $1.9 \mathrm{bc}$ & $2.1 \mathrm{ab}$ \\
\hline $0.1 \%$ IBA powder & 28 & 36 & $2.2 \mathrm{ab}$ & $1.1 \mathrm{~b}$ & 0.42 & 0.12 & $2.0 \mathrm{ab}$ & $2.1 \mathrm{ab}$ \\
\hline $0.3 \%$ IBA powder & 42 & 38 & $2.5 \mathrm{a}$ & $1.2 \mathrm{~b}$ & 0.41 & 0.14 & $2.3 \mathrm{a}$ & $2.1 \mathrm{ab}$ \\
\hline 1000 ppm IBA quick dip & 29 & 18 & $1.2 \mathrm{~cd}$ & $0.6 c$ & 0.26 & 0.09 & $2.0 \mathrm{ab}$ & $1.9 \mathrm{bc}$ \\
\hline
\end{tabular}

${ }^{z}$ Cuttings were either dipped in water and then auxin powder or held in the auxin liquid quick dip for $10 \mathrm{~s}$. Untreated cuttings were dipped in water. Cuttings were either placed in a peat perlite medium mixture or wrapped in damp paper towels. All cuttings were placed in a plastic bag to maintain a humid environment. All roots measured were formed at the base of the bud

${ }^{\mathrm{y}} \mathrm{l} \mathrm{ppm}=1 \mathrm{mg} \cdot \mathrm{L}^{-1}, 1 \mathrm{~cm}=0.3937$ inch.

${ }^{\mathrm{x}}$ Cutting that contained at least one root $\geq 2 \mathrm{~mm}(0.08$ inch $)$.

${ }^{\mathrm{w}} 0=$ dead; $\mathrm{l}=$ no callus or roots; 2 = callus formation; $3=$ few short roots; 4 = moderate well-developed roots; $5=$ many extensive roots.

"Means within the same column followed by the same letter are not significantly different according to a pairwise $t$ test $(P>0.05)$.

NS, * Nonsignificant or significant at $P \leq 0.05$, respectively.

cuttings that received liquid auxin treatments or untreated cuttings. This was in contrast with the paper towel method, for which untreated cuttings produced more roots than cuttings treated with auxin. Root rating results showed that untreated cuttings in the peat perlite mixture had a lower root rating compared with cuttings that received the $0.3 \%$ IBA powder treatment. With the paper towel method, cuttings treated with either $0.1 \%$ or $0.3 \%$ IBA powder or untreated cuttings had a higher root rating compared with cuttings that received the 3000-ppm IBA quick dip.

ExPт. 3. Repeated experiments were found to be homogenous; therefore, they were combined for analysis. Cuttings taken from older material from USDA-ARS were found to have a significantly higher rooting percentage $(22 \%)$ than those taken from younger material from NDSU (15\%) after 2 weeks across all auxin treatments. However, because the plant material with two different ages came from different locations, the impacts of plant age and location on rooting could not be determined. Cuttings treated with either $0.1 \%$ or $0.3 \%$ IBA powder produced more roots than did untreated cuttings or cuttings treated with either liquid IBA or NAA (Table 4). Root length results were somewhat similar, with cuttings treated with $0.1 \%$ IBA powder producing longer roots compared with untreated cuttings or cuttings treated with either liquid IBA or NAA, regardless of the concentration. Cuttings treated with $0.1 \%, 0.3 \%$, and $0.8 \%$ IBA powder as well as untreated cuttings had higher root ratings compared with cuttings that were quick-dipped in liquid. This was similar to what was observed during Expt. 2 , with $0.3 \%$ IBA having a higher root rating than the $3000 \mathrm{ppm}$ IBA using the paper towel method. It can be suggested that increasing auxin concentrations tended to result in lower root ratings, even across auxin types. The percent of cuttings that rooted was highest for cuttings treated with $0.1 \%$ IBA powder, followed by the untreated cutting and cuttings treated with $0.3 \%$ or $0.8 \%$ IBA powder. Cuttings that received either liquid IBA or NAA had the lowest rooting percentage.

\section{Discussion}

ExPT 1. With both rooting methods, most cultivars did not respond well to higher auxin concentrations in regard to rooting. Similar results were observed among all variables; higher auxin concentrations yielded poor results for cultivars that actually produced roots. Hartmann et al. (2011) stated that higher concentrations of auxin can have deleterious effects on cuttings and can cause death, but the concentrations used in the current study were not unusually high for hardwood cuttings. Busby and Himelrick (1999) recommended a range of 3000 to $8000 \mathrm{ppm}$ liquid dips for rooting softwood cuttings of blackberry and did not mention the deleterious effects on cuttings with higher concentrations. However, their quick dip was performed for only for $5 \mathrm{~s}$; during this experiment, the quick dip was performed for $10 \mathrm{~s}$. The additional length of time in the auxin solution may have been harmful at higher concentrations, or dormant cuttings may have been more sensitive to higher auxin concentrations.

The greater rooting success of 'Arapaho' and 'Ouachita' compared with 'Apache' and 'Kiowa' was somewhat surprising because all are erect cultivars and are typically propagated via root cuttings (Caldwell, 1984). The use of a trailing type of blackberry in this experiment may have resulted in even better rooting success because they are commonly propagated by tip layering and can easily produce adventitious roots (Caldwell, 1984; Crandall, 1995). However, Gonçalves et al. (2012) found that 'Ouachita' rooted better compared with 'Arapaho', and that 'Ouachita' rooted just as well as the trailing cultivar Karaka Black. Additionally, Lopez-Medina and Moore (1997) found that 'Arapaho' had the highest rooting success compared with three other erect cultivars; none of these was evaluated during this experiment.

These results indicated that the peat perlite mixture tends to produce more desirable results than using paper towels as a rooting environment. However, more resources and space would be required for the peat perlite mixture method; therefore, a grower would have to weigh the pros and cons of each method for a specific cultivar to determine if the costs would outweigh the benefits. 'Triple Crown', 'Apache', and 'Kiowa' had very limited rooting success with or without auxin. This was contrary to the results of Bray et al. (2003), 
Table 4. Effects of auxin treatment [indole-3-butyric acid (IBA), 1naphthaleneacetic acid (NAA)] on root length, root number, root rating, and percent of cuttings rooted for adventitious root production of one-node hardwood cuttings of 'Siskiyou' blackberry after 2 weeks in a rooting environment. ${ }^{\mathrm{z}}$

\begin{tabular}{lcccc}
\hline Auxin $^{\mathbf{y}}$ & $\begin{array}{c}\text { Rooted } \\
(\%)\end{array}$ & $\begin{array}{c}\text { Root } \\
\text { (ength }(\mathbf{c m})^{\mathbf{y}}\end{array}$ & $\begin{array}{c}\text { Root rating } \\
(\mathbf{0}-\mathbf{5} \text { scale })^{\mathbf{x}}\end{array}$ & $\begin{array}{c}\text { Roots } \\
(\mathbf{n o})^{\mathbf{w}}\end{array}$ \\
\hline Untreated & $44 \mathrm{~b}^{\mathrm{v}}$ & $0.09 \mathrm{~b}$ & $2.19 \mathrm{a}$ & $0.50 \mathrm{bc}$ \\
$0.1 \%$ IBA powder & $69 \mathrm{a}$ & $0.19 \mathrm{a}$ & $2.56 \mathrm{a}$ & $2.05 \mathrm{a}$ \\
$0.3 \%$ IBA powder & $38 \mathrm{~b}$ & $0.14 \mathrm{ab}$ & $2.13 \mathrm{a}$ & $1.62 \mathrm{a}$ \\
$0.8 \%$ IBA powder & $38 \mathrm{~b}$ & $0.11 \mathrm{~b}$ & $2.19 \mathrm{a}$ & $1.44 \mathrm{ab}$ \\
1000 ppm IBA quick dip & $6 \mathrm{c}$ & $0.01 \mathrm{c}$ & $1.63 \mathrm{~b}$ & $0.13 \mathrm{c}$ \\
3000 ppm IBA quick dip & $13 \mathrm{c}$ & $0.04 \mathrm{c}$ & $1.50 \mathrm{~b}$ & $0.31 \mathrm{c}$ \\
5000 ppm IBA quick dip & $6 \mathrm{c}$ & $0.01 \mathrm{c}$ & $1.38 \mathrm{~b}$ & $0.06 \mathrm{c}$ \\
8000 ppm IBA quick dip & $0 \mathrm{c}$ & $0.00 \mathrm{c}$ & $0.81 \mathrm{~cd}$ & $0.00 \mathrm{c}$ \\
1000 ppm NAA quick dip & $6 \mathrm{c}$ & $0.01 \mathrm{c}$ & $1.31 \mathrm{~b}$ & $0.13 \mathrm{c}$ \\
3000 ppm NAA quick dip & $0 \mathrm{c}$ & $0.00 \mathrm{c}$ & $1.19 \mathrm{bc}$ & $0.00 \mathrm{c}$ \\
5000 ppm NAA quick dip & $0 \mathrm{c}$ & $0.00 \mathrm{c}$ & $0.69 \mathrm{~d}$ & $0.00 \mathrm{c}$ \\
8000 ppm NAA quick dip & $0 \mathrm{c}$ & $0.00 \mathrm{c}$ & $0.38 \mathrm{~d}$ & $0.00 \mathrm{c}$ \\
\hline
\end{tabular}

${ }^{\mathrm{z}}$ Cuttings were held in the auxin liquid quick dip for $10 \mathrm{~s}$. Untreated cuttings were dipped in water. Cuttings were wrapped in damp paper towels. All cuttings were placed in a plastic bag to maintain a humid environment. The majority of roots measured were formed at the base of the bud.

${ }^{\mathrm{y}} \mathrm{l} \mathrm{ppm}=1 \mathrm{mg} \cdot \mathrm{L}^{-1}, \mathrm{l} \mathrm{cm}=0.3937$ inch.

${ }^{\mathrm{x}} 0$ = dead; 1 = no callus or roots; 2 = callus formation; 3 = few short roots; 4 = moderate well-developed roots; $5=$ many extensive roots.

${ }^{\mathrm{w}}$ Cuttings that contained at least one root $\geq 2 \mathrm{~mm}(0.08$ inch).

${ }^{v}$ Means followed by the same letter within a column are not significantly different according to a pairwise $t$ test $(P>$ $0.05)$

who reported that the best rooting occurred for 'Apache' with $0.3 \%$ auxin treatment and that rooting of 'Arapaho' decreased with the application of $0.3 \%$ auxin. The low root numbers indicated that this experiment had a low success rate regardless of cultivar, auxin, or rooting method, especially when compared with similar studies of hardwood cuttings (Bray et al., 2003; Gonçalves et al., 2012; Takeda et al., 2011; Zimmerman et al., 1980). However, these other studies involved hardwood cuttings from main stems and laterals of established plantings, not young plants maintained in nursery containers, which may have had a role in their limited success. Gonçalves et al. (2012) reported that the rooting percentage of two-node cuttings taken from the top one-third of 'Ouachita' plants $(>2 \mathrm{~m})$ was approximately three-times greater than that of the cuttings taken from the bottom onethird of the plants $(0-1 \mathrm{~m})$. Unfortunately, the plant and stem size of the young containerized plants used in the current study were reduced; most stems were only $1 \mathrm{~m}$ in length, with short, thin laterals. Annual blackberry production systems in northern climates will require mother plants to be grown in containers because injurious low temperatures often occur in November, before the required chilling is fulfilled.

EXPT. 2. Similar rooting by 'Siskiyou' and 'Triple Crown' was not expected because Takeda et al. (2011) reported that 'Siskiyou' produced higher rooting percentages than 'Triple Crown' in similar experiments. In the current study, all of the roots formed at the base of the buds of one-node cuttings, consistent with the results of Takeda et al. (2011), whereas Zimmerman et al. (1980) reported that roots formed at the base of the cut end and the bud placed below the medium of three-node hardwood cuttings. This phenomenon seems to occur only with hardwood cuttings and is not fully understood. Greater root numbers and root ratings for cuttings that received $0.1 \%$ or $0.3 \%$ IBA powder in the peat perlite mixture strengthened the results reported by Bray et al. (2003), who used a similar rooting method, regarding root ratings for 'Apache' and 'Navaho'.

Expt. 3. The use of plants with two different ages was performed to determine whether the age of the plants from which cuttings were taken or the way in which they were grown had an impact on adventitious root production. Low winter temperatures result in cane injury; therefore, the ability to store plants in a cooler would be valuable for an annual production system in northern climates. However, because the plants with two different ages were from different locations, it could not be determined whether the age of the plants or the location from which they came impacted rooting.

The goal of this experiment was to determine the best auxin treatment for adventitious rooting in 'Siskiyou', which is a cultivar that was reported by Takeda et al. (2011) to have good hardwood rooting success, even into January. It is possible that rooting success for this cultivar was lower than that reported by Takeda et al. (2011), because the cuttings from USDAARS were not placed in a rooting environment the same day that they were cut. The general trend observed was that the untreated and powder form of auxin performed better than the liquid quick dips. Hartmann et al. (2011) noted that the liquid quick dips generally performed better than powder auxins of similar concentrations because the powder did not adhere very well to the cuttings, resulting in variable concentrations of the auxin being applied to the cuttings. However, they also mentioned that, although not common, powder-based auxins have been found to be more successful than liquid dips in certain instances. This may also be the case with hardwood blackberry cuttings; however, during Expt. 2, no differences were found between the liquid and powder auxin of similar concentrations regarding root length or percent rooted. Because 'Siskiyou' cuttings treated with the lowest auxin powder treatment (0.1\% IBA powder) increased the rooting percentage, root number, and root length compared with the untreated cuttings, even lower auxin concentrations may be required to increase adventitious root production of hardwood blackberry cuttings.

Additional experiments other than these three were conducted, but they were not reported here because the results were of no significance or the cuttings died. Considering that two nodes might produce two flower shoots per rooted cutting, the use of two-node cuttings compared to one-node cuttings was evaluated; however, none of the cuttings produced roots. Different rooting 
media were evaluated, including Oasis cubes (Oasis Rootcubes; Oasis Grower Solutions, Kent, $\mathrm{OH}$ ), sand, and perlite, in addition to the paper towel and peat perlite mixture. However, no differences were found for these media, and the overall rooting success was low. Additionally, 'Triple Crown' and 'Siskiyou' cuttings from 12 - and 2 -year-old mother plants were evaluated with NAA quick dip compared with IBA quick dip with two different concentrations, but no rooting differences were found.

Although data regarding shoot formation and growth in these experiments were not presented, it was noted that most of the cuttings did break bud and produce a shoot, even though no roots were produced. These shoots eventually died because they had no means to take up water and nutrients, or they desiccated quickly when removed from the humid rooting environment. Cuttings were held in the same environment for an additional 2 weeks during some studies to see if rooting improved; for example, Takeda et al. (2011) reported transplanting cuttings after 4 weeks. However, the longer the cuttings were held in the rooting environment, the more they seemed to decline; in some instances, the formed roots started to rot. Occasionally, a strong cutting would continue to develop roots, and these were transplanted. Those that did survive produced inflorescences and, subsequently, fruit.

\section{Conclusions}

The low adventitious root numbers observed for all the experiments indicated that this method of blackberry propagation in the Northern Great Plains region is not viable at this time. It will be necessary for cuttings of FF blackberries to be taken as hardwood if they are to be used in an annual production system in regions such as the Northern Great Plains. There are currently no widely accepted recommendations for hardwood blackberry cuttings with regard to auxin concentrations or an appropriate rooting method. Previous research as well as the current study suggested that any recommendation with regard to auxin concentrations or rooting method would be inappropriate due to the poor and variable rooting responses. Results from this study as well as prior work suggested that rooting of hardwood blackberry cuttings will vary from cultivar to cultivar and also with auxin treatments within cultivars, despite the type of rooting method used (Bray et al., 2003; Gonçalves et al., 2012; LopezMedina and Moore, 1997; Takeda et al., 2011; Zimmerman et al., 1980). The results also suggested that even though containerized mother plants would be needed for hardwood FF blackberry cuttings if an annual production system were to be used in the Northern Great Plains region, the 3 -qt nursery containers were inadequate because stem material was much shorter compared with material used by other researchers; therefore, cuttings were taken more toward the basal region. Acclimatization of cuttings from their rooting environment to a growing environment is of importance, but all of the rooting methods that were tried during this study had marginal acclimatization success. Because most of the cultivars used in this study are patented, individuals who would want to use these cultivars commercially for hardwood cuttings would have to obtain the appropriate licensing agreements to avoid violating patent laws. Adventitious root production of one-node dormant hardwood FF blackberry cuttings for use in an annual production system had low success rates regardless of the cultivar, auxin application, rate, and formulation. Although this approach to developing plants from cuttings is of great interest, without a more effective FF blackberry cutting rooting method that can progress through fruit production, an annual blackberry production system in the Northern Great Plains region is unlikely at this time.

\section{Literature cited}

Bray, M.M., C.R. Rom, and J.R. Clark. 2003. Propagation of thornless Arkansas blackberries by hardwood cuttings. Discovery (Univ. Arkansas) 4:1:9-13.

Busby, A.L. and D.G. Himelrick. 1999. Propagation of blackberries (Rubus spp.) by stem cuttings using various IBA formulations. Acta Hort. 505:327-332.
Caldwell, J.D. 1984. Blackberry propagation: A review. HortScience 19:13-15.

Clark, J.R. 2013. 'Osage' thornless blackberry. HortScience 48:909-912.

Clark, J.R. and J.N. Moore. 1999. 'Apache' thornless blackberry. HortScience 34:1291-1293.

Clark, J.R. and J.N. Moore. 2005. 'Ouachita' thornless blackberry. HortScience 40:258-260.

Crandall, P.C. 1995. Bramble production: The management and marketing of raspberries and blackberries. Food Prod. Press, Binghamton, NY.

Finn, C.E., F.J. Lawrence, B.C. Strik, B. Yorgey, and J. DeFrancesco. 1999. 'Siskiyou' trailing blackberry. HortScience 34:1288-1290.

Galletta, G.J., J.L. Maas, J.R. Clark, and C.E. Finn. 1998. 'Triple Crown' thornless blackberry. Fruit Var. J. 52:124-127.

Gonçalves, D.M., C.M. Oliveira, L. Lopesda-Fonseca, and P.B. Oliveira. 2012. Blackberry production by floricane stem cuttings. Acta Hort. 946:379-381.

Hartmann, H.T., D.E. Kester, F.T. Davies, Jr., and R.L. Geneve. 2011. Plant propagation: Principles and practices. 8th ed. Prentice Hall, Upper Saddle River, NJ.

Lopez-Medina, J. and J.N. Moore. 1997. Propagation of erect blackberries by floricane stem cuttings. HortScience 32:602 (abstr.).

Mettler, D. and H. Hatterman-Valenti. 2018. Rotating cross-arm and winter rowcovers for floricanes blackberry (Rubus subgenus Rubus Watson) production in North Dakota. HortScience 53:1813.

Moore, J.N. and J.R. Clark. 1993. 'Arapaho' erect thornless blackberry. HortScience 28:861-862.

Moore, J.N. and J.R. Clark. 1996. 'Kiowa' blackberry. HortScience 31:286288.

Takeda, F. and J. Soria. 2011. Method for producing long-cane blackberry plants. HortTechnology 21:563-568.

Takeda, F., T. Tworkoski, C.E. Finn, and C.C. Boyd. 2011. Blackberry propagation by non-leafy floricane cuttings. HortTechnology 21:236-239.

Zimmerman, R.H., G.J. Galleta, and O.C. Broome. 1980. Propagation of thornless blackberries by one-node cuttings. J. Amer. Soc. Hort. Sci. 105:405-407. 